\title{
The Relationship of Grammatical Judgment and Implicit Learning in 4- to 6-Year-Old Children with and without Specific Language Impairment
}

\author{
Yoonhee Yang, Dongsun Yim \\ Department of Communication Disorders, Ewha Womans University, Seoul, Korea
}

Correspondence: Dongsun Yim, PhD Department of Communication Disorders, Ewha Womans University, 52 Ewhayeodae-gil, Seodamun-gu, Seoul 03760, Korea

Tel: $+82-2-3277-6720$

Fax: $+82-2-3277-2122$

E-mail: sunyim@ewha.ac.kr

Received: January 3, 2017

Revised: February 16, 2017

Accepted: March 3, 2017

This work was supported by the Ewha Womans University Research Grant.

\begin{abstract}
Objectives: This study examined cognitive flexibility in implicit learning through manipulating item frequency and predictive probability in children with and without specific language impairment (SLI). The purpose of this study was to determine whether a significant difference in non-linguistic implicit learning ability would be found between children with SLI and their typically developing (TD) peers and identify a significant factor for distinguishing between SLI and TD groups. Methods: Sixteen 4- to 6-year-old children with SLI and 15 age-matched children with TD participated in this study. Accuracy and RTs were obtained via the Grammatical Judgment Task (GJT) and non-linguistic implicit learning task, where item frequencies and probability were considered simultaneously. The accuracy (\%) and response time (ms) in the implicit learning task were recorded using E-Prime Software. A repeated measure of ANOVA, Pearson's product moment correlation coefficient, and discriminant analysis were used for data analysis. Results: The results showed that the SLI group had significantly lower accuracy and longer response time on the implicit learning task than the TD group; a significant difference between low frequency/low probability and the other conditions between the SLI and the TD groups was found only for accuracy; and RT in $\mathrm{HL}$ (conflict high frequency/low relational probability) condition was a significant factor for identifying SLI. Conclusion: When compared to peer TD children, children with SLI are less sensitive to certain rules if both frequency and probability are at lower levels. These difficulties are closely associated with their grammatical judgment performance.
\end{abstract}

Keywords: Implicit learning, Children with language impairment, Grammatical judgment, Joint probability, Cognitive flexibility
암묵적 학습(implicit learning)이란, 경험을 통해서 의도적으로 지시 받거나 의식하지 않고도 패턴 또는 규칙이 포함된 새로운 정 보를 학습할 수 있는 능력을 말한다. 복잡한 환경 속에서의 다양한 자극들 가운데 인접 가능성이 높은 자극끼리 함께 나올 확률을 계 산하고 추출해낼 수 있는 암묵적 또는 통계적 학습능력은 개인이 가지고 태어나는 선천적인 능력일 것으로 보기도 하며(Perruchet $\&$ Pacton, 2006), 생애 첫 1 년 동안의 경험을 통해 생성된다고 보기 도 한다(Gomez \& Gerken, 1999; Klinger, Klinger, \& Pohlig, 2007; Vicari, Marotta, Menghini, Molinari, \& Petrosini, 2003). 이 능력
은 아기들이 복잡하고 긴 성인의 말소리를 쪼개어 문장을 구로, 구 를 단어로, 단어를 음절로 인식할 수 있게 하는 데에 핵심적인 역할 을 해줄 수 있는 것으로 보았다(Gomez \& Gerken, 1999; Jeong \& Yim, 2016; Maye, Werker, \& Gerken, 2002; Park, \& Kim, 2015; Saffran, Aslin, \& Newport, 1996; Saffran \&Wilson, 2003; Saffran, 2003; Yim \& Rudoy, 2013; Yim \& Windsor, 2010).

언어 습득과 관련하여 '암묵적 학습’(implicit learning)은 '통계 적 학습(statistical learning)', '인공 문법 학습(artificial grammar learning)', '절차적 학습(procedural learning)'과 같이 다양한 용어 
Yoonhee Yang, et al. • The Relationship of Grammatical Judgment and Implicit Learning

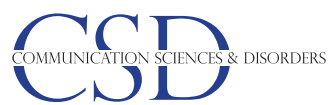

로도 불리며, 최근 이러한 표현들은 환경 속 다양한 자극들의 인접 성과 규칙성을 찾아내어 적절하게 부호화하여 유용한 정보들을 효 율적으로 학습할 수 있는지에 주목하고 있다(Evans, Saffran, \& Robe-Torres, 2009; Fitch \& Friederici, 2012; Gomez \& Gerken, 1999; Lum, Conti-Ramsden, Morgan, \& Ullman, 2014; Saffran et al., 1996; Saffran, 2003; Tomblin, Mainela-Arnold, \& Zhang, 2007). 암묵적 또는 통계적 학습은 언어 처리(language processing), 음소배열 패 턴 습득(Saffran, Newport, Aslin, Tunick, \& Barrueco, 1997), 말소 리에서의 어휘 경계 발견(Evans et al., 2009), 문법 능력(Ullman, 2004)을 포함한 다양한 언어 및 언어학습 능력과 밀접하게 연결될 수 있다. 그 중에서도 문법 능력은 '절차적 학습' 이라는 암묵적 기 억의 한 유형에 의해 처리되는 언어적 규칙 학습으로, 특히 단순언 어장애 아동의 언어적인 결함뿐만 아니라 처리속도와 같은 비언어 적 처리 결함을 모두 설명하기 위한 가설로 Ullman과 Pierpont (2005)는 절차적 결함 가설(Procedural Deficit Hypothesis, PDH) 을 제시하였다.

절차 기억 시스템(procedural memory system)은 단순언어장애 아동의 주요한 어려움인 언어 영역에서 나타나는 문법 결함뿐 아니 라 운동 및 인지 기술, 작업기억 과제 수행 전반에서도 어려움을 보 인다는 것을 증명해주는 뇌의 시스템을 말한다(Lum et al., 2014; Tomblin et al., 2007; Ullman \& Pierpont, 2005). 절차적 기억은 새 로운 순서를 일반화하고 학습하는 것을 돕는데, 학습 시 의식적으 로 접근하지 않기 때문에 ‘암묵적 기억 시스템’이라고도 불린다. 즉, 이 시스템을 통해 특히 연속적 또는 추상적인 새로운 규칙을 배울 수 있으므로 언어에서는 특히 문법적 측면과 긴밀한 연관성이 있으 며, 복잡한 형태론 및 구문 구조를 저장하는 것뿐만 아니라 작업기 억(working memory), 빠른 속도로 처리될 것이 요구되는 일시적 처리(temporal processing)도 절차적 시스템(procedural system)과 긴밀한 연관성을 보이는 것으로 보고되고 있다(Gabriel, Stefaniak, Maillart, Schmitz, \& Meulemans, 2012; Ullman \& Pierpont, 2005). Ullman (2004)에 따르면, 절차적 기억으로 학습하는 것은 의미 또 는 어휘적 지식을 담당하는 서술적 기억으로 학습하는 것보다 속 도는 느리지만 한 번 습득되면 그 기술을 빠르게 실행할 수 있다고 하였다. 특히 단순언어장애 아동은 '순서'와 관련된 운동기술에서 의 어려움이 존재하며(Zelaznik \& Goffman, 2010), 서술적 기억보 다 상대적으로 절차적 기억에서의 결함이 두드러진다는 보고도 있 었다(Lum \& Bleses, 2012; Lum \& Conti-Ramsden, 2013). 선행연 구를 통해 단순언어장애 아동은 일반 아동에 비해 특히 구문적 지 식과 관련된 조사처리 영역에서 더욱 어려움을 보이며, 문법형태소 는 명사나 동사와 같은 내용어에 비해 내포하는 정보가 적고, 기능
적인 역할을 수행하므로 언어발달지연 아동들에게 특히 어려운 요 소로 알려져 있다(Kamhi \& Koening, 1985; Yim, Yang, Jo, Lee, \& Seong, 2015). 이 경우 잔존하는 서술적 기억이 절차적 기억이 담당 하는 문법 규칙을 보완할 수 있다고 보았다(Bishop, 2002; Hill, 2001; Lum, Conti-Ramsden, Page, \& Ullman, 2012). 그러나, 단순언어장 애 아동들의 언어에서의 결함은 문법에 한정적이기보다는 음운, 의 미, 어휘에 걸쳐 전반적으로 다양하게 나타나며, 특히 '어휘'에서의 결함을 보이는 단순언어장애 아동의 경우에는 절차적 기억 시스템 의 결함을 보상해줄 수 있는 서술적 기억 시스템에서의 상대적인 강점이 존재한다고 보기 어렵다. 따라서, 어휘 결함이 두드러지는 단순언어장애 아동의 경우 역시 절차적 기억 및 암묵적 학습 과제 수행에서 어려움을 보일 가능성이 매우 높다고 볼 수 있다.

단순언어장애 아동들의 암묵적 학습능력을 다룬 선행연구에 의 하면, 암묵적 학습에서의 어려움은 언어적 정보를 접할 때뿐만 아 니라 비언어적인 정보를 학습할 때에도 나타날 수 있어 이들의 결 함이 보다 전반적인 정보처리 영역에 걸쳐서 나타날 수 있음을 추 론해볼 수 있다(Conway, Pisoni, Anaya, Karpicke, \& Henning, 2011; Desmottes, Meulemans, \& Maillart, 2016; Lukács \& Kemény, 2014; Yim \& Windsor, 2010). 특히 선행연구에서는 정보를 제시 하는 방법을 시각 또는 청각으로 달리하거나(Conway \& Christiansen, 2005, 2009; Saffran, 2003; Yim \& Rudoy, 2013), 순차적 또는 동시적으로 제시해봄으로써(Conway \& Christiansen, 2005) 비언 어적인 정보로 구성된 자극을 암묵적으로 학습하는 능력이 언어 능력을 유의하게 예측해줄 수 있는지를 세부적으로 확인하고자 하 였다. Conway와 Christiansen (2005)의 연구에서는 자극을 '동시 적'으로 제시할 때 청각 암묵적 학습에 비해 시각 암묵적 학습 수행 이 더 나았던 반면, 자극을 '순차적'으로 제시할 때 시각 암묵적 학 습 수행에 비해 청각 암묵적 학습 수행이 더 나았음을 입증하였다. Lukács와 Kemény (2014)는 단순언어장애 아동들의 '순차적 암묵 적 학습 능력이 특정 영역에서가 아닌 전반적인 정보처리 영역에 서 나타나는 결함인 것으로 보았다.

한편, 목표자극 및 규칙에 대한 민감성과 학습된 규칙이 위반될 때 행동을 조절하는 인지적 유연성은 환경과 효율적으로 상호작용 하는 데에 핵심적인 역할을 한다(Amso \& Davidow, 2012). 환경적 인 통제에 의한 암묵적 학습의 발달은 자극의 빈도뿐만 아니라 자 극 간 관계와 확률에 대한 암묵적인 인식 모두의 영향을 받아 이루 어진다. 단순히 빈도가 적은 목표자극을 마주했을 때보다 예측이 되지 않는 정보들을 직면했을 때 행동을 조절하는 것은 더욱 어렵 기 때문이다. 기존의 암묵적 학습능력을 측정하는 연구 과제들이 자극의 제시방법이 청각 또는 시각적인지, 동시적 또는 순차적인지 
에 주목했지만, 제시되는 자극의 빈도를 고려함과 동시에 목표자 극과 그 앞의 단서의 인접하는 확률을 동시에 조작해봄으로써 각 조건에 따른 암묵적 학습능력이 다른 양상으로 나타날 수 있는지 살펴볼 필요가 있다. 여기서 '단서-목표자극의 조합확률'이란, '어 떤 목표자극이 특정 단서의 뒤에 인접하여 나올 확률을 의미한다. 목표자극의 출현 빈도와 조건-목표자극의 조합확률이 모두 높은 조건에서 높은 수행을 보인 아동은 그렇지 않은 아동에 비해 과제 내 규칙에 보다 민감한 것으로 추론해볼 수 있다. 또한, 목표자극의 출현 빈도는 동일하게 높게 유지되면서 조건-목표자극의 조합확률 은 낮은 갈등조건에서 높은 수행을 보이는 아동은 인지적으로 높 은 유연성을 지닐 가능성이 높다. 이때 목표자극이 언어적인 자극 이 아닐 지라도 규칙에 대한 민감성을 지닌 아동은 언어 내 규칙인 '문법'의 세부 규칙을 탐지하는 데에도 보다 세심할 수 있다. 따라서 본 연구의 암묵적 학습 과제 제작 시 목표자극은 비언어자극인 시 각적 자료를 활용하였으며, 단서-목표단어의 조합확률과 목표단어 의 빈도와 함께 고려하여 목표단어의 높은 빈도 및 단서-목표단어 의 높은 조합확률 $(\mathrm{HH})$, 목표단어의 높은 빈도 및 단서-목표단어 의 낮은 갈등조합확률 $(\mathrm{LH})$, 목표단어의 낮은 빈도 및 단서-목표단 어의 낮은 조합확률 $(\mathrm{LL})$ 로 과제 조건을 세분화하였다.

전통적인 절차적 운동학습의 한 유형인 연속 반응시간 과제(Serial Reaction Time task, SRT; originally by Nissen \& Bullemer, 1987) 는 절차적 기억 능력을 확인할 수 있는 대표적인 과제로, 대상 아동 들이 화면에서 3-4개의 위치에서 나타나는 시각적(비언어적) 자극 에 반응하도록 고안되었으며, 정확도뿐만 아니라 반응속도를 측정 할 수 있다는 장점을 지닌다. 이 과제를 통해 학습효과는 의식하지 않아도 증가할 수 있음을 볼 수 있다(Jiménez, 2008). 대상 아동들 은 사전지식이 필요 없이 순차적으로 반복되는 규칙에 따라 빠르 게 규칙에 반응하여 버튼을 누르게 된다. 무작위로 제시되는 자극 에 대한 반응에 비해 규칙이 반복되는 노출 빈도가 증가할수록 반 응속도는 빨라지게 되는데 이는 곧 학습이 이루어졌다는 증거가 될 수 있다(Cohen, Ivry, \& Keele, 1990; Curran \& Keele, 1993; Nissen \& Bullemer, 1987). 즉, 학습이 된 이후부터는 다음 자극이 어디 에서 나타날 것인지 기대하면서 학습하게 된다. 예상했던 대로 다 음 자극이 나오게 되면 자신이 통계적으로 수립한 규칙에 더욱 의 존하게 되고, 그것이 보다 효율적인 학습으로 이끌어줄 수 있다. 연 속 반응시간 과제는 시각적인 과제로, 두드러진 언어 사용을 요구 하지는 않기 때문에 아이들의 언어 수준이 이 과제를 수행하는 데 에 직접적인 영향을 주지 않을 것을 가정한다. 즉, 연속 반응시간 과 제와 같은 시각적 과제에서는 청각 및 음운정보 처리에 대한 요구 가 배제된다. 그럼에도 불구하고, 단순언어장애 아동이 이 과제수
행 하에서도 일반 아동보다 패턴 학습에 부족함을 보인다면, 이들 의 결함이란 단순히 말소리를 듣고 처리하는 언어적, 청각적 지각 에서의 어려움 때문만이 아닌 청각 및 시각영역 전반에 걸친 제한 인 것으로 설명될 수 있을 것이다(Archibald \& Gathercole, 2007; Miller, Kail, Leonard, \& Tomblin, 2001; Schul, Stiles, Wulfeck, \& Townsend, 2014; Ullman \& Pierpont, 2005). 그러므로, 언어와 문 법에서 부족함을 보이는 것이 비언어적 순서 규칙을 학습하는 것 과 직접적으로 관련이 있다면, 언어와 문법 학습과 관련된 인지구 조는 '전반적인' 순서적 패턴을 학습하는 것과 밀접한 상관관계를 가지는 것으로 볼 수 있다(Tomblin et al., 2007).

연속적 패턴을 학습하는 것이 단순언어장애, 언어발달지체 그리 고 난독증 아동들에게 불가능한 것만은 아니다. 이 아동들 역시 연 속적 패턴을 학습할 수 있는데, 상대적으로 일반 아동들에 비해 학 습이 이루어지기까지 더 많은 기회와 시간이 필요할 뿐이다. 특히, 과제 전반의 수행을 관장하는 특정 규칙에 대한 민감도가 부족하 므로 이들의 효율적인 학습을 위해서는 더 많은 기회와 두드러진 (salient) 규칙 패턴을 제공하는 것이 필요하다. 그러나 만약, 이 아 동들에 대해 단지 아주 단순한 규칙 및 패턴을 학습할 때에는 또래 일반 아동과 유의한 차이를 보이지 않고, 상대적으로 더욱 복잡한 난이도에서의 절차적 정보 학습 시 특히 어려움을 보인다고 가정한 다면, 이들의 세부적인 어려움과 요구를 확인하기 위해 단순히 목 표자극에 대한 발생 빈도만을 조절해주기보다는 운동 또는 인지적 요구를 충분히 요구하는 복합 과제를 사용하거나 서로 다른 위치 에서 발생하는 다양한 목표자극과 환경적 단서의 관계까지 고려하 여 살펴봐야 한다는 필요성이 제기된다(Gabriel et al., 2012). Gabriel 등(2012)의 연구에서도 키보드가 아닌 터치 스크린 방식으로 과제의 운동 및 인지적 요구를 축소시켰더니 단순언어장애 아동과 또래 일반 아동의 차이는 유의하지 않았다. 또한, 시공간적 연속 반 응시간 과제를 통해 정확도와반응시간을 함께 측정한 Lum 등(2012) 의 연구에서 단순언어장애 아동은 또래 일반 아동과 비교하여 '정 확도'에서는 유의미한 차이를 보이지 않았지만, ‘반응속도' 측면에 서 살펴봤을 때는 일반 아동이 절차에 대한 효율적 학습이 가능하 기 때문에 반응속도가 짧아진 반면, 단순언어장애 아동은 절차적 학습상의 효율성이 부족하여 반응속도가 길어져 그룹 간 유의한 차이가 나타났다. 이 연구를 통해 절차 및 암묵적 학습을 보다 심층 적으로 살펴보기 위해서는 정확도뿐만 아니라 반응속도도 함께 살 펴보는 것이 중요함을 알 수 있다.

따라서 본 연구에서는 빈도와 더불어 단서-목표자극 조합의 확 률을 조정함에 따라 단순언어장애 및 또래 일반 아동의 암묵적 학 습 과제 수행의 패턴이 다르게 나타나는지를 살펴본다면, 각각의 
집단에서 목표자극 및 규칙 민감성과 인지적 유연성이 암묵적 학 습수행능력에 각각 어떻게 기여하고 함께 작용하는지에 대한 고찰 이 가능하기에 이에 대해 살펴보고자 한다. 또한, 이러한 암묵적 학 습 수행능력이 각 집단의 문법성 판단 과제 수행능력과 어떤 상관 관계를 가지고 있고 그룹에 따라 다른 상관관계가 나타나는지, 암 묵적 학습 수행능력은 문법성 판단 과제를 예측해줄 수 있는지, 그 리고 단순언어장애 유무를 가장 잘 판별해주는 암묵적 학습 과제 의 조건은 무엇인지 살펴보고자 한다.

연구질문은 다음과 같다.

1) 목표자극의 빈도와 단서-목표자극의 조합확률에 따라 암묵 적 학습의 수행은 달라지는가? 암묵적 학습 과제의 수행에서 빈도가 적은 목표자극을 마주했을 때보다, 단서-목표자극의 조합확률이 낮을 때 정확도 및 반응속도 각각의 측면에서 모 두 어려움을 보이는가?

2) 단순언어장애 및 일반 아동 집단 각각에서 암묵적 학습 과제 는 언어과제(문법성 판단)와 통계적으로 유의한 상관관계를 보이는가?

3) 단순언어장애 유무를 가장 잘 판별해줄 수 있는 암묵적 학습 과제의 조건은 무엇인가?

\section{연구 방법}

\section{연구 대상}

본 연구는 만 4-6세의 단순언어장애 아동 16명, 그리고 생활연령 을 \pm 3 개월범위 내로 일치시킨 일반아동 15 명, 총 31 명을 대상으로 하였다. 참여는 모두 부모의 동의 하에 이루어졌다.

본 연구에 참여한 단순언어장애 아동은 (1) 초등학교 및 유치원 담임교사 및 주양육자에 의해 인지, 신체능력이 정상 범주에 속하 나 언어발달에 어려움이 있는 것으로 보고되고, (2) 카우프만 아동 용 지능검사(Korean Kaufman Assessment Battery for Children, K-ABC; Moon \& Byun, 2003)의 비언어성 지능지수가 85점(-1 SD) 이상이며, (3) 수용 및 표현어휘력검사(Receptive and Expressive Vocabulary Test, REVT; Kim, Hong, Kim, Jang, \& Lee, 2009) 결과 수용 및 표현어휘력 점수 모두 자신의 생활연령 기준에서 $-2 \mathrm{SD}$ 미 만이며, (4) 정서, 행동, 감각(시각 및 청각), 사회적 상호작용 등의 문 제가 없고, 기타 신경학적 결함의 이력이 없는 아동으로 선정하였다.

본 연구에 참여한 일반아동은 (1) 아동의 주양육자 또는 초등학 교 및 유치원 담임교사에 의해 언어, 인지 및 신체능력이 정상 범주 에 속하는 것으로 보고되고, (2) 카우프만 아동용 지능검사(K-ABC; Moon \& Byun, 2003)의 비언어성 지능지수가 85점(-1 SD) 이상이
며, (3) 수용 및 표현어휘력검사(REVT; Kim et al., 2009) 결과 수용 및 표현어휘력 점수가 모두 정상 범주(-1 SD 이상)에 속하며, (4) 정 서, 행동, 감각(시각 및 청각), 사회적 상호작용 등의 문제가 없고, 기 타 신경학적 결함의 이력이 없는 아동으로 선정하였다.

단순언어장애 아동 집단의 평균 생활연령은 $69.3(\mathrm{SD}=6.18)$ 개 월, 또래 일반 아동 집단의 생활연령은 $68.9(\mathrm{SD}=11.84)$ 개월이었다. 단순언어장애아동 집단의 비언어성 지능 평균은 $101.8(\mathrm{SD}=11.21)$ 점이고, 일반아동들 집단의 비언어성 지능 평균은 $108.3(\mathrm{SD}=12.13)$ 점이었다. 또한, 단순언어장애아동 집단의 수용어휘력은 $46.1(\mathrm{SD}=$ 7.89)점, 일반 아동 집단의 수용어휘력은 $72.3(\mathrm{SD}=18.14)$ 이고, 단 순언어장애 아동 집단의 표현어휘력은 $54.1(\mathrm{SD}=8.55)$ 점, 일반 아 동 집단의 표현어휘력은 $77.7(\mathrm{SD}=12.16)$ 점이었다.

두 집단의 통제가 잘 이루어졌는지 확인하기 위해 일원분산분석 (one-way ANOVA)을 실시한 결과, 연령 및 비언어성 지능에 통계 적으로 유의한 차이가 없었고 $(p>.05)$, 수용어휘력 $\left(F_{(1,30)}=27.69\right.$, $p<.001)$ 및 표현어휘력 $\left(F_{(1,30)}=39.74, p<.001\right)$ 에 대한 집단 간 차이 가 통계적으로 유의하게 나타났다. 두 집단 아동들의 생활연령, 비 언어성 지능, 수용 및 표현 어휘력 점수의 평균 및 표준편차는 Table 1 에 제시하였다.

\section{연구 도구}

본 연구에서는 만 4-6세의 단순언어장애 아동 및 또래 일반 아 동들의 암묵적 학습능력을 빈도 및 단서-목표자극의 조합확률의 조정에 따라 다각도로 분석해보기 위해 빈도 및 조합확률 조건을 high/high, high/low, low/low의 3가지로 나누어 제작한 암묵적 학 습 과제 수행의 집단 간 차이를 살펴보고, 이 암묵적 학습 과제와 문법성 판단 과제(Grammatical Judgment Task)가 얼마나 유의한 상관관계가 있는지, 단순언어장애 판별에 유용한 암묵적 학습 과 제의 조건은 무엇인지 확인하고자 아래와 같은 연구 과제들을 실시 하였다.

Table 1. Participants' characteristics

\begin{tabular}{lcrc}
\hline & SLI (N=16) & TD (N=15) & \multicolumn{1}{c}{$F$} \\
\hline Age (mo) & $69.31(6.18)$ & $68.87(11.84)$ & .02 \\
Nonverbal IO ${ }^{a}$ & $101.81(11.21)$ & $108.27(12.13)$ & 2.37 \\
REVT-R $^{b}$ & $54.06(8.55)$ & $77.73(12.16)$ & $27.69^{* * *}$ \\
REVT-E $^{b}$ & $46.13(7.89)$ & $72.27(18.14)$ & $39.74^{* * *}$ \\
\hline
\end{tabular}

Values are presented as mean (SD).

$S L I=$ children with specific language impairment; $T D=$ children with typically developing.

aKorean Kaufman Assessment Battery for Children (Moon \& Byun, 2003), ${ }^{\text {'Recep- }}$ tive \& Expressive Vocabulary Test (Kim, Hong, Kim, Jang, \& Lee, 2010). ${ }^{* * *} p<.001$. 
빈도와 조합확률을 고려한 암묵적 학습 과제(Implicit learning considering frequency and joint probability)

본 연구과제는 Amso와 Davidow (2012)의 연구에서 사용된 암 묵적 학습과제의 아이디어 및 기본구조를 토대로 제작되었다.

실험과제의 조건은 총 3 가지로, 화면 정중앙에 제시되는 단서 (cue)의 종류는 2 가지(거북이, 꽃게)이며 이 단서와 함께 목표자극 (target)인 3가지(노란색, 하늘색, 분홍색 돌고래)와 공간적 위치(오 른쪽, 왼쪽, 위)를 보고 아동은 목표자극(target)인 돌고래를 보면 3 가지 방향키 중 한 가지를 골라 버튼을 눌러야 한다. 각 방향키에는 또한 해당되는 각 색깔 셀로판지가 부착되어 있다. 예를 들어, 노란 색 돌고래는 항상 단서의 오른쪽 방향키(노란색 부착), 하늘색 돌고 래는 항상 단서의 왼쪽 방향키(하늘색 부착), 분홍색 돌고래는 항 상 단서의 위(분홍색 부착)에 위치한다. 그러므로 아동이 모니터에 노란색 돌고래가 나타났을 때 오른쪽 버튼을 누르면 정반응, 그 외 버튼을 누르면 오반응이다. 동시에, 목표자극의 출현 빈도도 변화 하는데 이는, 단서와 연결되어서 목표자극이 제시되는 관계와는 독립적으로 이루어진다. 2 가지 단서(cue)인 거북이와 꽃게가 제시 되는 확률은 3 가지 실험과제 모두에서 $50 \%$ 로 동일하며, 단서-목표 자극이 연속적으로 나타날 확률과 빈도는 의도적으로 조작된다. 예를 들어, 실험과제 $1(\mathrm{HH})$ 에서 단서(cue)인 거북이 다음에 목표 자극(target)인 노란색 돌고래가 올 확률은 $75 \%$ 로 높고, 비 목표자 극(un-target)인 파란색 돌고래가 올 확률은 $25 \%$ 로 낮다. 실험과제 2 (conflict L/H)에서 단서(cue)인 꽃게 다음에 목표자극(target)인 노란색 돌고래가 나올 확률은 25\%로 낮고, 비 목표자극(un-target) 인 분홍색 돌고래가 올 확률은 $75 \%$ 로 높다. 실험과제 1 과 2 모두에 서 목표자극(target)인 노란색 돌고래는 각각 $50 \%$ 로 비교적 높은 빈도로 출현한다. 한편, 실험과제 $3(\mathrm{~L} / \mathrm{L})$ 에서 단서(cue)인 거북이 다음에 목표자극(target)인 하늘색 돌고래가 나올 확률은 $25 \%$ 로 낮고, 비 목표자극(un-target)인 분홍색 돌고래가 올 확률은 $75 \%$ 로 높다. 실험과제 3 에서 목표자극(target)인 하늘색 돌고래의 출현 빈 도는 12.5 로 실험과제 1,2 에서 목표자극의 빈도가 $50 \%$ 인 것과 비 교하여 빈도가 매우 낮다. 각 실험과제 조건 당 100 개의 단서-목표 자극 짝이 과제 안에 삽입되어 있다. 이중 분석의 대상이 되는 측정 변수는 3가지 실험과제 내 각각의 목표자극(target)에 대한 정확도 와 반응속도로, 비 목표자극(un-target)에 대한 정확도와 반응속도 자료는 분석의 대상이 되지 않는다.

대상 아동들에게 흰 바탕 화면 중앙에 단서(cue) 그리고 주변에 목표자극(target)이 연속적으로 제시된다. 단서(cue)와 목표자극 (target)의 제시기간은 $1,000 \mathrm{~ms}$ 이며, 자극 간 간격(inter stimulus interval) 또한 $1,000 \mathrm{~ms}$ 이다. 대상 아동들은 컴퓨터 모니터에 나타
나는 목표자극인 돌고래가 제시되면 그 자극을 보고 할 수 있는 한 빠르게 목표자극의 색깔 및 위치가 고려된 3 가지 버튼 중 해당하는 버튼을 누를 수 있도록 했다. 연구자가 대상 아동들에게 지시한 구 체적인 과제 설명은 다음과 같다. "OO야, 지금부터 돌고래 잡기 게 임을 할거야. $\mathrm{OO}$ 이는 돌고래 말고 다른 것이 나오면 누르면 안되 고, 돌고래만 잡을 거야. 노란색 돌고래는 $\rightarrow$ (노란색), 하늘색 돌고래 는 $\leftarrow$ (하늘색), 분홍색 돌고래는 $\uparrow($ 분홍색)을 눌러서 잡으면 돼. 그 럼 시작해보자!” 모든 아동들은 충분한 연습을 거친 후에 본 실험 과제를 수행하였다. 전반적인 과제에 대한 내용을 Appendix 1에 수 록하였다.

\section{문법성 판단 과제(Grammatical Judgment Task)}

본 연구의 문법성 판단 과제는 E-Prim 2.0으로 제작된 것으로, 대상 아동들이 주어진 문장을 듣고 문법적인 형태가 옳은지 또는 그른지를 판단하는 능력을 측정하기 위해 사용하였다. 과제의 문 항은 총 30 문항이며 정문 15 개, 비문 15 개로 구성되어있다. 예를 들 어, '삽으로 땅을 파요'는 정문에 속하며, '가위로 종이에서 잘라요' 는 비문에 속한다. 이처럼 본 연구에서 판단이 요구되는 문법적 요 소는 '조사'이고, 주격 조사는 '-이', '-가'를 사용하였고, 목적격 조 사는 '-을, '-를' 을, 처소격조사는 '-에', 그리고 도구격 조사는 '-로' 를 사용하였다.

아동은 컴퓨터 화면에 제시된 그림자극과 그림을 설명하는 음성 이 제시되면 컴퓨터에 붙여진 특정버튼 $(\mathrm{O}, \mathrm{X})$ 를 가능한 빨리 눌러 서 정오판단을 수행하여야 한다. 즉, 아동은 시각적으로 제시되는 그림과 청각적으로 제시되는 문장을 접하고 문장이 적절하다고 생 각되면 $\mathrm{O}$ 를 누르고, 적절하지 않다고 생각하면 $\mathrm{X}$ 를 눌러야 하는 것이다. 아동이 반응키를 누르면 곧바로 다음 문항으로 넘어간다. 검사는 조용한 방에서 검사자와 아동 1:1로 랩탑 컴퓨터를 이용하 여 이루어졌으며 5 개의 연습문항을 통해 검사자의 지시를 올바로 이해했는지 확인한 후 본 문항으로 넘어가도록 하였다.

\section{자료분석 및 결과처리}

본 연구에서 사용된 과제들은 모두 정반응 1 점, 오반응은 0 점으 로 계산되었으며, 암묵적 학습 과제 및 문법성 판단 과제의 정반응 률은 백분율(\%)로 산출하였다. 암묵적 학습 과제의 반응속도는 EPrime 2.0을 통해 자동으로 기록되도록 하였으며, 반응시간의 계 산은 오직 아동이 정반응한 시간만을 포함하여 평균을 구했다. 단, 아동의 반응시간이 $100 \mathrm{~ms}$ 미만으로 과제 수행을 위해 충분하지 않다고 판단될 경우 제외하였으며, 특히 아동의 반응이 평균에서 $\pm 2 \mathrm{SD}$ 바깥으로 벗어날 경우 가외치(outlier)로 간주하여 제외하 
Yoonhee Yang, et al. • The Relationship of Grammatical Judgment and Implicit Learning

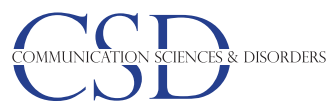

였다(Kail, 1994).

본 연구의 모든 통계적 분석은 SPSS ver. 19 (SPSS Inc., Chicago, $\mathrm{IL}, \mathrm{USA}$ )를 사용하였다. 결과분석은 빈도 및 조합확률에 따른 집 단 간 암묵적 학습 과제 수행의 차이를 알아보기 위해 집단(2) $\times$ 과 제 내 조건(3)을 독립변인으로 하는 반복측정 이원분산분석(repeated two-way ANOVA)을 실시하였다. 또한, 각 집단의 암묵적 학습능력과 문법성 판단 과제 간 상관관계를 알아보기 위해 Pearson의 적률상관계수(Pearson's product-moment correlation coefficient)를 산출하였으며, 빈도 및 조합확률을 변화시킨 암묵적 학 습 과제의 각 조건 중 단순언어장애 판별을 위한 가장 강력한 요인 은 무엇인지 알아보고자 판별분석(discriminant analysis)을 실시 하였다.

\section{연구 결과}

\section{두 집단 간 빈도 및 조합확률에 따른 암묵적 학습 과제 수행의 정확도 및 반응속도}

반복측정 이원분산분석 결과, 암묵적 학습 과제에서 단순언어 장애 아동 집단은 또래 일반 아동 집단의 수행보다 통계적으로 유 의하게 낮은 정확도를 보였다 $\left(F_{(1,29)}=4.459, p<.05\right)$. 조건에 따른 암 묵적 학습 수행 또한 통계적으로 유의하였다 $\left(F_{(2,58)}=7.467, p<.01\right)$ 이에 따라, Bonferroni 사후분석을 실시한 결과, 빈도 및 조합확률 이 둘 다 낮은 조건(Low/Low)은 둘 다 높은 조건(High/High) 및 갈등조건(Low/High)과 비교했을 때 통계적으로 유의하게 낮은 수 행을 보였다 $(p<.05)$. 집단 및 조건의 상호작용 효과는 나타나지 않 았다 $\left(F_{(2,58)}=.626, p>.05\right)$. 이에 대한 결과를 Figure 1 에 제시하였다.

단순언어장애 아동 집단과 또래 일반 아동 집단의 빈도 및 조합

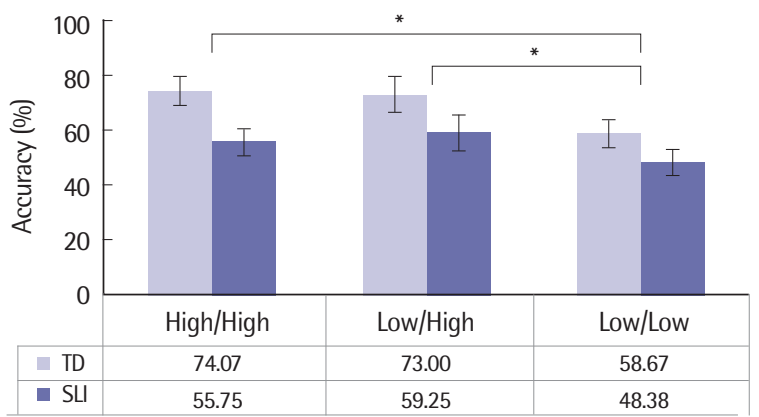

Figure 1. Accuracy of implicit learning for each group and condition. High/ High=high relational probability/high frequency; Low/High= conflict low relational probability/high frequency; Low/Low = low relational probability/low frequency; $S L I=$ children with specific language impairment; $T D=$ children with typically developing. ${ }^{*} p<.05$
확률 조건에 따른 과제수행의 반응속도 결과를 살펴보면, 단순언 어장애 아동 집단은 또래 일반 아동 집단의 수행과 비교했을 때 통 계적으로 유의하게 느린 반응속도를 보였다 $\left(F_{(1,29)}=9.531, p<.01\right)$. 조건에 따른 암묵적 학습 수행 반응속도는 통계적으로 유의하지 않았으며 $\left(F_{(2,58)}=2.281, p>.05\right)$, 집단 및 조건의 상호작용 효과도 나 타나지 않았다 $\left(F_{(2,58)}=2.550, p>.05\right)$. 이에 대한 결과를 Figure 2에 제시하였다.

\section{두 집단(SLI/TD)의 암묵적 학습능력과 문법성 판단 능력의 관계}

단순언어장애 및 일반아동 집단 각각에서 각 조건에 따른 암묵 적 학습능력이 문법성 판단 능력과 유의미한 상관이 나타나는지 알아보기 위해 Pearson의 상관계수를 살펴보았다. 그 결과, 단순언 어장애 아동 집단에서는 문법성 판단-비문(U)과 암묵적 학습 세 부조건 중 빈도 및 조합확률이 모두 낮은 경우의 정확도 $(r=.631$, $p<.01)$ 와 반응속도 $(r=-.548, p<.05)$ 에서 통계적으로 유의한 상관 관계를 보였다. 또래 일반 아동 집단에서는 문법성 판단-정문 $(\mathrm{G})$ 과 암묵적 학습 세부조건 중 빈도 및 조합확률이 모두 낮은 경우의 정 확도 $(r=.609, p<.05)$, 문법성 판단-비문(U)과는 암묵적 학습 세부 조건 중 빈도 및 조합확률이 모두 높은 경우의 정확도 $(r=-.649, p<$ $.01)$, 조합확률은 낮고 빈도는 높은 갈등조건의 정확도 $(r=-.599, p<$ .05)에서 통계적으로 유의한 상관관계를 보였다. 이에 대한 결과는 Tables 2, 3 과 같다.

\section{단순언어장애 유무를 가장 잘 판별해주는 암묵적 학습 과제의 조건}

본 연구에서 사용된 암묵적 학습 과제의 빈도 및 조합확률에 따 른 3 가지 조건 중 단순언어장애 및 또래 일반 아동 집단 각각을 가

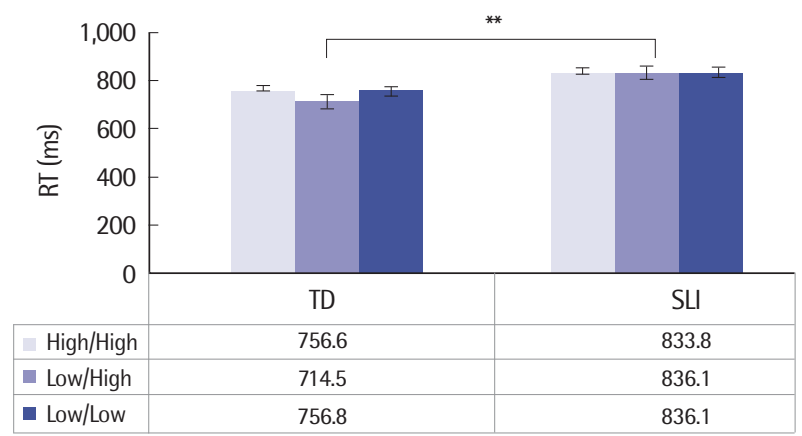

Figure 2. Response time (RT) of implicit learning for each group and condition. High/High=high relational probability/high frequency; Low/High= conflict low relational probability/high frequency; Low/Low = low relational probability/low frequency; $S L I=$ children with specific language impairment; $T D=$ children with typically developing. ${ }^{* *} p<.01$. 
Table 2. The correlations coefficient for tasks in children with specific language impairment

\begin{tabular}{lccccccc}
\hline & $G$ & U & HH_Acc & LH_Acc & LL_Acc & HH_RT & LH_RT \\
\hline U & .161 & & & & & & \\
HH_Acc & .032 & .421 & & & & & \\
LH_Acc & -.092 & .422 & $.920^{* *}$ & & & & \\
LL_Acc & .382 & $.631^{* *}$ & .435 & .475 & & & \\
HH_RT & -.070 & -.099 & $-.585^{*}$ & $-.638^{* *}$ & -.385 & & \\
LH_RT & .032 & -.076 & $-.852^{* *}$ & $-.826^{* *}$ & -.250 & $.794^{* *}$ & \\
LL_RT & .071 & $-.548^{*}$. & -.439 & $-.503^{*}$ & $-.688^{* *}$ & $.631^{* *}$ & .437 \\
\hline
\end{tabular}

$\mathrm{G}=$ grammatical judgment; $\mathrm{U}=$ ungrammatical judgment; $\mathrm{HH}=$ high relational probability/high frequency; $L H=$ conflict low relational probability/high frequency; $L L=$ low relational probability/low frequency; $A c c=$ accuracy; $R T=$ response time.

${ }^{*} p<.05,{ }^{* *} p<.01$.
Table 3. The correlations coefficient for tasks in typically developing children

\begin{tabular}{lccccccc}
\hline & $G$ & U & HH_Acc & LH_Acc & LL_Acc & HH_RT & LH_RT \\
\hline U & -.172 & & & & & & \\
HH_Acc & .374 & $-.649^{* *}$ & & & & & \\
LH_Acc & .020 & $-.599^{*}$ & $.779^{* *}$ & & & & \\
LL_Acc & $.609^{*}$ & -.016 & .488 & .409 & & & \\
HH_RT & -.335 & .323 & $-.727^{* *}$ & -.494 & -.424 & & \\
LH_RT & -.161 & .166 & $-.527^{*}$ & -.396 & -.455 & $.877^{* *}$ & \\
LL_RT & -.173 & .048 & -.381 & -.248 & -.436 & $.854^{* *}$ & $.968^{* *}$ \\
\hline
\end{tabular}

$\mathrm{G}=$ grammatical judgment; $\mathrm{U}=$ ungrammatical judgment; $\mathrm{HH}=$ high relational probability/high frequency; $L H=$ conflict low relational probability/high frequency; $L L=$ low relational probability/low frequency; $\mathrm{Acc}=\mathrm{accuracy} ; \mathrm{RT}=$ response time. ${ }^{*} p<.05,{ }^{* *} p<.01$.

Table 4. Classification table from stepwise discriminate analysis

\begin{tabular}{ccccccccc}
\hline & Independent variable & $\chi^{2}$ & Wilks's lambda $(p$-value $)$ & $\eta^{2}$ & Specificity $(\%)$ & Sensitivity $(\%)$ & Total $(\%)$ & $p$-value \\
\hline Model 1 & LH_RT & 8.710 & $.737(<.01)$ & .263 & 60.0 & 75.0 & 67.7 & $<.01$ \\
\hline
\end{tabular}

$\mathrm{LH}=$ conflict low relational probability/high frequency; $\mathrm{RT}=$ response time.

장 잘 판별할 수 있는 요소는 무엇인지 살펴보고자 단계선택방식 의 판별분석(stepwise estimation-discriminate analysis)을 실시하 였다. 즉, 대상 아동들의 집단 특성을 가장 잘 판별할 수 있는 판별 함수를 도출하고, 독립변수의 상대적 기여도를 파악하기 위해 단 계적 판별분석방법을 선택하였다. 투입된 독립변수는 빈도 및 조합 확률이 모두 높은 조건(HH)의 정확도와 반응속도, 조합확률은 낮 지만 빈도는 높은 갈등 조건(LH)의 정확도와 반응속도, 빈도 및 조 합확률이 모두 낮은 조건(LL)의 정확도와 반응속도로 총 6 가지를 입력하였다. 이에 대한 세부적인 결과는 Table 4 와 같다.

그 결과, 도출된 판별함수로부터 입력된 6가지의 독립변수 중에 서 LH (conflict low relational probability/high frequency) 조건의 반응속도(RT)가 집단을 가장 정확히 예측할 수 있는 통계적으로 유의한 요인인 것으로 분석되었다. 이 판별함수에 의하면 모델 1 에 서 일반아동을 일반아동으로 판별하는 특이도(specificity)는 $60.0 \%$, 단순언어장애 아동을 단순언어장애 아동으로 판별하는 민감도 (sensitivity)는 75.0\%로 원 집단 케이스 중 총 $67.7 \%$ 가 올바르게 분 류될 수 있는 것으로 나타났다 $\left(\chi^{2}=8.710, p<.01\right)$.

\section{논의 및 결론}

본 연구는 빈도 및 조합확률에 따른 집단 간 암묵적 학습 과제 수 행의 차이를 알아보고, 각 집단의 암묵적 학습능력과 문법성 판단 과제 간 상관관계를 확인하였으며, 빈도 및 조합확률에 따른 암묵 적 학습 과제의 각 조건 중 단순언어장애 판별을 위한 가장 강력한
요인은 무엇인지 알아보았다.

첫째, 암묵적 학습 과제에서 단순언어장애 아동 집단은 또래 일 반 아동 집단의 수행보다 통계적으로 유의하게 낮은 정확도를 보였 으며, 느린 반응속도를 보였다. 단순언어장애 아동이 본 연구실험 과제의 모든 조건에서 저조한 수행을 보이게 된 것은 목표자극 자 체에 대한 민감도 부족, 그리고 아동 스스로 암묵적으로 수립한 단 서와 목표자극 간의 연결고리가 또래 일반 아동에 비해 긴밀하지 않았던 것에 기인한다. 한편, 조건에 따른 수행으로는 빈도 및 조합 확률이 둘 다 낮은 조건(LL)은 둘 다 높은 조건(HH) 및 갈등조건 (LH)과 비교했을 때 통계적으로 유의하게 정확도가 낮았다. 이와 같은 단순언어장애 아동의 암묵적 학습의 결함은 이들의 절차적 기억 손상으로부터 기인한다고 볼 수 있으며, 이러한 결함이 부족 한 언어기술을 설명한다(Ullman, 2004). 또한, 선행연구에서 단순 언어장애 아동이 청각적 정보를 사용한 암묵적 학습에서 결함을 보인 것과 같이, 본 연구에서 사용한 것과 같은 시공간적 정보를 사 용한 암묵적 학습에서도 낮은 정확도와 느린 반응속도를 보일 수 있음을 확인할 수 있다(Evans et al., 2009; Lum et al., 2014). 본 연 구에서 사용한 과제는 시공간적인 과제로, 명백한 언어 사용을 요 구하지는 않기 때문에 또래 일반 아동에 비해 단순언어장애 아동 들의 부족한 언어 수준이 이 과제를 수행하는 데에 직접적인 영향 을 주지 않을 것을 전제하였다. 즉, 최대한 단순언어장애 아동들의 불이익을 최소화했음에도 불구하고 시공간적 자극을 사용한 단순 언어장애 아동들의 암묵적 학습 과제 수행의 어려움이 나타난 것 은 단순히 이들의 청각적인 지각 및 음운정보 처리에서의 어려움이 
아닌 청각 및 시각 도메인을 모두 아우르는 광범위한 절차적 학습 의 제한으로 설명할 수 있을 것이다(Ullman \& Pierpont, 2005). 특 히, 조합확률 뿐만 아니라 빈도가 낮은 조건에서 특히 단순언어장 애 아동들의 암묵적 학습능력은 통제집단에 비해 유의하게 부족 하게 나타났으므로, 통제집단과 유사한 빠르고 자동적인 처리가 이루어지기 위해서는 학습이 요구되는 목표자극에 대한 반복적인 트레이닝이 추가적으로 요구될 수 있다(Lum et al., 2014). 한편, 조 건 및 집단 간 상호작용이 나타나지 않은 것은 단순언어장애 아동 이 저조한 수행을 보이지만 그 패턴은 또래 일반 아동과 유사한 것 에 의한 것으로 추론된다. 즉, 본 연구에서 단순언어장애 아동들이 모든 실험과제 조건을 불문하고 전반적으로 낮은 정확도와 느린 반 응속도를 보였지만 이들의 암묵적 과제 수행에서의 어려움은 독특 한 특성을 지닌다기보다는 또래 일반 아동과 유사한 패턴을 보이며 상대적으로 시각 및 운동을 포함한 전반적인 측면에서 저장 및 처 리의 제한을 보이는 것에 의한 것임을 확인할 수 있다(Archibald \& Gathercole, 2007; Miller et al., 2001; Schul et al., 2014). 따라서, 단 순언어장애 아동들의 저장 및 처리의 효율을 높이기 위해 구어 및 비구어적 자극에 관계없이 학습을 위해 더 많은 시도와 기회가 제 공되어야 하며 과제 전반에 걸친 규칙에 대한 민감도를 높여주는 것이 필요하다. 그렇게 되면 다음 자극이 어디에서 나타날 것인지 무의식적일지라도 기대하면서 학습할 수 있고, 예상한 대로 다음 자극이 제시되면 자신이 통계적으로 수립한 규칙에 더욱 의존하게 되면서 보다 효율적인 학습을 가능하게 할 수 있다.

둘째, 또한, 단순언어장애 아동 집단에서는 문법성 판단-비문(U) 과 빈도 및 조합확률이 모두 낮은 정확도(LL_Acc)와 반응속도( $\mathrm{LL}_{-}$ $\mathrm{RT})$ 에서만 통계적으로 유의한 상관관계를 보였으며, 또래 일반 아 동 집단에서는 문법성 판단-정문 $(\mathrm{G})$ 과 빈도 및 조합확률이 모두 낮 은 정확도 $\left(\mathrm{LL} \_\mathrm{Acc}\right)$, 문법성판단-비문(U)과는 빈도 및 조합확률이 모두 높은 정확도(HH_Acc), 조합확률은 낮고 빈도는 높은 갈등조 건의 정확도(LH_Acc)에서 통계적으로 유의한 상관관계를 보였다. 즉, 단순언어장애 아동의 문법성 판단 과제의 수행은 암묵적 학습 과제에서 조합확률과 빈도가 모두 낮았던 조건만이 높은 상관관계 를 보였는데, 이는 단순언어장애 아동들이 주된 패턴이나 규칙을 자연스럽게 습득하기보다는, 단서와 목표자극 간의 핵심적인 연결 고리를 발견하지 못하거나 목표자극의 빈도에 민감하게 반응하지 못하기 때문인 것으로 분석된다(Evans et al., 2009). 반면, 또래 일 반아동들의 문법성 판단 과제 수행은 빈도 및 조합확률을 조작한 3 가지 조건 모두와 높은 관련성을 보였다. 이는 언어에서의 문법적 특성 역시 예외 없는 절대적 규칙이라기 보다는 규칙 및 불규칙이 혼재하는 특성을 지니고 있으며, 암묵적 학습에서의 다양하게 조
작된 3 가지 조건이 모두 이들의 문법성 판단 과제 수행에 정적인 상 관성을 지니는 것은 상대적으로 더 나은 이들의 인지적 유연성 $(\operatorname{cog}-$ nitive flexibility)에 기인하는 것으로도 볼 수 있다.

셋째, LH (conflict low relational probability/high frequency) 조 건의 반응속도(RT)가 단순언어장애 및 또래 일반 아동 판별에 약 $67.7 \%$ 기여할 수 있는 것으로 분석되었다. 빠른 반응속도는 학습이 이루어졌다는 증거가 될 수 있는데, 특히 단순언어장애 아동의 경 우 전통적인 연속 반응시간(SRT) 과제에서는 통제 집단 아동들과 유사한 정확도와 속도로 학습할 수 있더라도, 더 높은 난이도의 통 계적 구조와 순서를 지닌 연속 반응시간 과제 수행에서는 단순언어 장애 아동이 또래 일반아동에 비해 더 느린 반응속도를 보이거나 특정 순서를 학습했다는 결과를 얻지 못했다고 하였다(Gabriel et al., 2013; Jiménez, 2008). 이는, 과제 내에서 목표자극의 높은 빈도 는 유지되지만 단서와 목표자극 간의 조합확률은 낮은 조건의 경 우 두 가지 조건 간의 갈등을 유발하므로 빈도 및 조합확률 모두 높 을 경우에 비해 상대적으로 규칙 및 패턴을 확립하는 데에 인지적 갈등을 유도하므로 반응속도를 길게 하는 데에 공헌한다고 볼 수 있다. 또한, 갈등조건은 각 정보들이 비일관적으로 제공되는 환경이 조성된다고 볼수 있어 역시 난이도는 증가된다고 볼수 있다(Amso \& Davidow, 2012). 이러한 조건이 단순언어장애 및 또래 일반 아동 집단으로 정확하게 판별하는 데에 주요한 요인으로 작용할 수 있었 던 것으로 보인다.

결론적으로 단순언어장애 아동은 과제 전반의 수행을 관장하는 특정 규칙에 대한 민감도가 또래 일반아동 집단 아동에 비해 상대 적으로 부족하며, 빈도 및 조합확률이 모두 낮은 조건과 문법성 판 단 수행과 유의한 상관이 나타나 빈도 및 조합확률이 모두 높은 조 건, 갈등조건, 모두 낮은 조건 등 모든 조건에서 문법성 판단 수행과 유의한 상관이 나타나 인지적 유연성을 보인 일반 아동과 차이를 보였다. 또한, 갈등조건(LH)의 반응속도(RT)가 그룹 간 판별에 통 계적으로 유의하게 기여하였으므로 규칙 및 패턴을 확립하기 위해 빈도 및 조합확률이 비일관적으로 제공되어 인지적 갈등이 유발되 는 본 과제의 갈등조건이 과제 복잡성을 높이므로 이것이 특히 각 그룹의 판별에 유의한 기여를 할 수 있었다고 볼 수 있다. 특히 본 연 구에서는 언어적으로 어려움을 보이는 단순언어장애 아동들의 본 연구의 암묵적 학습 과제 수행상의 불이익을 최소화하고자 비언어 적인 시공간 자극을 사용하였다. 그럼에도 불구하고 단순언어장애 아동들은 수행력 저하를 보였으므로 이들의 학습을 위해 구어 및 비구어 자극에 관계없이 더 많은 시도와 기회가 제공되어 규칙에 대한 민감도를 높여주는 것이 필요할 수 있다. 즉, 이들의 저장 및 처 리의 효율을 높여주기 위해 자신이 암묵적으로 수립한 규칙을 기 
반으로 삼아 다음 자극의 학습에 적용 또는 변형할 수 있도록 돕는 것이 필요하다. 연구의 제한점으로는 본 연구의 대상이었던 단순언 어장애 아동들이 표준화 어휘검사의 수용 및 표현점수 및 부모의 보고만을 토대로 선정되었다는 점이다. 후속 연구에서는 어휘를 포 함하여 보다 전반적인 언어검사를 통해 선정된 단순언어장애 아동 들의 더 나은 규칙학습 및 문법적 장치의 인식을 위해 이들에게 유 용하게 적용될 수 있는 다양한 목표자극과 환경적 단서의 관계를 문법을 포함한 전반적 언어 영역으로의 적용 방법에 대해 보다 깊 이 있게 살펴볼 필요가 있다. 이러한 후속 연구를 통해 단순언어장 애 아동의 순서적 패턴 학습에 대해 더욱 폭넓은 시사점을 얻을 수 있을 것이다. 더불어 문법 영역뿐 아니라 음소 패턴의 인식, 어휘 습 득과 같은 영역과 암묵적 학습능력과의 관계를 심층적으로 살펴본 다면 언어 능력과 암묵적 학습능력 간 더욱 광범위한 논의가 가능 할 것으로 보인다.

\section{REFERENCES}

Amso, D., \& Davidow, J. (2012). The development of implicit learning from infancy to adulthood: item frequencies, relations, and cognitive flexibility. Developmental Psychobiology, 54, 664-673.

Archibald, L. M., \& Gathercole, S. E. (2007). The complexities of complex memory span: storage and processing deficits in specific language impairment. Journal of Memory and Language, 57, 177-194.

Bishop, D. V. (2002). Motor immaturity and specific speech and language impairment: evidence for a common genetic basis. American Journal of Medical Genetics Part A, 114, 56-63.

Cohen, A., Ivry, R. I., \& Keele, S. W. (1990). Attention and structure in sequence learning. Journal of Experimental Psychology: Learning, Memory, and Cognition, 16, 17-30.

Conway, C. M., \& Christiansen, M. H. (2005). Modality-constrained statistical learning of tactile, visual, and auditory sequences. Journal of Experimental Psychology: Learning, Memory, and Cognition, 31, 24-39.

Conway, C. M., \& Christiansen, M. H. (2009). Seeing and hearing in space and time: Effects of modality and presentation rate on implicit statistical learning. European Journal of Cognitive Psychology, 21, 561-580.

Conway, C. M., Pisoni, D. B., Anaya, E. M., Karpicke, J., \& Henning, S. C. (2011). Implicit sequence learning in deaf children with cochlear implants. Developmental Science, 14, 69-82.

Curran, T., \& Keele, S. W. (1993). Attentional and nonattentional forms of sequence learning. Journal of Experimental Psychology: Learning, Memory, and Cognition, 19, 189-202.

Desmottes, L., Meulemans, T., \& Maillart, C. (2016). Implicit spoken words and motor sequences learning are impaired in children with specific language impairment. Journal of the International Neuropsychological Society, 22, 520-529.

Evans, J. L., Saffran, J. R., \& Robe-Torres, K. (2009). Statistical learning in children with specific language impairment. Journal of Speech, Language, and Hearing Research, 52, 321-335.

Fitch, W. T., \& Friederici, A. D. (2012). Artificial grammar learning meets formal language theory: an overview. Philosophical Transactions of the Royal Society B, 367, 1933-1955.

Gabriel, A., Maillart, C., Stefaniak, N., Lejeune, C., Desmottes, L., \& Meulemans, T. (2013). Procedural learning in specific language impairment: effects of sequence complexity. Journal of the International Neuropsychological Society, 19, 264-271.

Gabriel, A., Stefaniak, N., Maillart, C., Schmitz, X., \& Meulemans, T. (2012). Procedural visual learning in children with specific language impairment. American Journal of Speech-Language Pathology, 21, 329-341.

Gomez, R. L., \& Gerken, L. (1999). Artificial grammar learning by 1-year-olds leads to specific and abstract knowledge. Cognition, 70, 109-135.

Hill, E. L. (2001). Non-specific nature of specific language impairment: a review of the literature with regard to concomitant motor impairments. International Journal of Language \& Communication Disorders, 36, 149-171.

Jeong, P. Y., \& Yim, D. (2016). Relationship between implicit learning and phonological awareness in children with articulation and phonological disorders. Communication Sciences \& Disorders, 21, 37-46.

Jiménez, L. (2008). Taking patterns for chunks: is there any evidence of chunk learning in continuous serial reaction-time tasks? Psychological Research, 72, 387-396.

Kail, R. (1994). A method for studying the generalized slowing hypothesis in children with specific language impairment. Journal of Speech, Language, and Hearing Research, 37, 418-421.

Kamhi, A. G., \& Koenig, L. A. (1985). Metalinguistic awareness in normal and language-disordered children. Language, Speech, and Hearing Services in Schools, 16, 199-210.

Kim, Y. T., Hong, G. H., Kim, K. H., Jang, H. S., \& Lee, J. Y. (2009). Receptive \& expressive vocabulary test (REVT). Seoul: Seoul Community Rehabilitation Center.

Klinger, L. G., Klinger, M. R., \& Pohlig, R. L. (2007). Implicit learning impairments in autism spectrum disorders. In J. M. Perez (Ed.), New Developments 
in Autism: The Future is Today (pp. 76-103). London: Jessica Kingsley Publishers.

Lukács, A., \& Kemény, F. (2014). Domain-general sequence learning deficit in specific language impairment. Neuropsychology, 28, 472-483.

Lum, J. A., \& Bleses, D. (2012). Declarative and procedural memory in Danish speaking children with specific language impairment. Journal of Communication Disorders, 45, 46-58.

Lum, J. A., \& Conti-Ramsden, G. (2013). Long-term memory: a review and meta-analysis of studies of declarative and procedural memory in specific language impairment. Topics in Language Disorders, 33, 282-297.

Lum, J. A., Conti-Ramsden, G., Morgan, A. T., \& Ullman, M. T. (2014). Procedural learning deficits in specific language impairment (SLI): a meta-analysis of serial reaction time task performance. Cortex, 51, 1-10.

Lum, J. A., Conti-Ramsden, G., Page, D., \& Ullman, M. T. (2012). Working, declarative and procedural memory in specific language impairment. Cortex, 48, 1138-1154.

Maye, J., Werker, J. F., \& Gerken, L. (2002). Infant sensitivity to distributional information can affect phonetic discrimination. Cognition, 82, B101-B111.

Miller, C. A., Kail, R., Leonard, L. B., \& Tomblin, J. B. (2001). Speed of processing in children with specific language impairment. Journal of Speech, Language, and Hearing Research, 44, 416-433.

Moon, S. B., \& Byun, C. J. (2003). Korean Kaufman assessment battery for children $(K-A B C)$. Seoul: Hakjisa.

Nissen, M. J., \& Bullemer, P. (1987). Attentional requirements of learning: evidence from performance measures. Cognitive Psychology, 19, 1-32.

Park, Y. J., \& Kim, Y. T. (2015). Explicit and implicit learning ability of children with reading disabilities seen through the task of artificial grammar learning. Communication Sciences \& Disorders, 20, 518-535.

Perruchet, P., \& Pacton, S. (2006). Implicit learning and statistical learning: one phenomenon, two approaches. Trends in Cognitive Sciences, 10, 233238.

Saffran, J. R. (2003). Statistical language learning mechanisms and constraints. Current Directions in Psychological Science, 12, 110-114.
Saffran, J. R., \& Wilson, D. P. (2003). From syllables to syntax: multilevel statistical learning by 12-month-old infants. Infancy, 4, 273-284.

Saffran, J. R., Aslin, R. N., \& Newport, E. L. (1996). Statistical learning by 8-monthold infants. Science, 274, 1926-1928.

Saffran, J. R., Newport, E. L., Aslin, R. N., Tunick, R. A., \& Barrueco, S. (1997). Incidental language learning: listening (and learning) out of the corner of your ear. Psychological Science, 8, 101-105.

Schul, R., Stiles, J., Wulfeck, B., \& Townsend, J. (2004). How 'generalized' is the 'slowed processing' in SLI? The case of visuospatial attentional orienting. Neuropsychologia, 42, 661-671.

Tomblin, J. B., Mainela-Arnold, E., \& Zhang, X. (2007). Procedural learning in adolescents with and without specific language impairment. Language Learning and Development, 3, 269-293.

Ullman, M. T. (2004). Contributions of memory circuits to language: the declarative/procedural model. Cognition, 92, 231-270.

Ullman, M. T., \& Pierpont, E. I. (2005). Specific language impairment is not specific to language: the procedural deficit hypothesis. Cortex, 41, 399-433.

Vicari, S., Marotta, L., Menghini, D., Molinari, M., \& Petrosini, L. (2003). Implicit learning deficit in children with developmental dyslexia. Neuropsychologia, 41, 108-114.

Yim, D., \& Rudoy, J. (2013). Implicit statistical learning and language skills in bilingual children. Journal of Speech, Language, and Hearing Research, 56, 310-322.

Yim, D., \& Windsor, J. (2010). The roles of nonlinguistic statistical learning and memory in language skill. Korean Journal of Communication Disorders, 15, 381-396.

Yim, D., Yang, Y., Jo, Y., Lee, J., \& Seong, J. (2015). Grammatical meta-linguistic awareness and executive functioning skills in preschool-age children with and without specific language impairment. Journal of Speech \& Hearing Disorders, 24, 345-359.

Zelaznik, H. N., \& Goffman, L. (2010). Generalized motor abilities and timing behavior in children with specific language impairment. Journal of Speech, Language, and Hearing Research, 53, 383-393. 
Appendix 1. Experimental task conditions

\begin{tabular}{|c|c|c|c|c|}
\hline No. & Condition & Cue & Relational probability & Target frequency \\
\hline 1 & $\begin{array}{l}\text { High relational probability/high } \\
\text { frequency item (Cue1/Tar- } \\
\text { get1) }\end{array}$ & Turtle (50\%) & Yellow dolphin (75\%, 39 trials) & $\begin{array}{l}\text { Yellow dolphin } \\
\text { (50\%, } 52 \text { trials) }\end{array}$ \\
\hline 2 & $\begin{array}{l}\text { Conflict low relational proba- } \\
\text { bility/high frequency item } \\
\text { (Cue2/Target1) }\end{array}$ & Crab (50\%) & Yellow dolphin (25\%, 13 trials) & $\begin{array}{l}\text { Yellow dolphin } \\
\text { (50\%, } 52 \text { trials) }\end{array}$ \\
\hline 3 & $\begin{array}{l}\text { Low relational probability/ } \\
\text { low frequency item } \\
\text { (Cue1/Target2) }\end{array}$ & Turtle (50\%) & Blue dolphin (25\%, 13 trials) & $\begin{array}{c}\text { Blue dolphin } \\
(12.5 \%, 13 \text { trials) }\end{array}$ \\
\hline
\end{tabular}




\section{국문초록}

\section{4-6세 단순언어장애 및 일반아동의 암묵적 학습 및 문법성 판단 능력의 관계 양윤희 · 임동선 \\ 이화여자대학교 대학원 언어병리학과}

배경 및 목적: 본 연구에서는 만 4-6세 아동의 암묵적 학습능력을 알아보기 위하여 목표자극의 빈도와 함께 단서-목표자극의 조합확 률 또한 중요하게 고려될 수 있는 요인인지, 빈도 및 조합확률이 모두 높은 조건에서의 암묵적 학습 수행이 그렇지 않은 조건들에 비해 문법성 판단 과제와 가장 유의한 상관이 있는지, 단순언어장애 유무를 가장 잘 판별해줄 수 있는 요인은 무엇인지 알아보고자 하였다. 방법: 만 4-6세의 단순언어장애 아동 16명, 또래 일반 아동 15 명 총 31 명을 대상으로 문법성 판단 과제, 목표자극의 빈도 및 단서-목표 자극의 조합확률을 고려한 암묵적 학습 과제를 실시하였다. 결과: 암묵적 학습 과제에서의 수행은 그룹 간 유의한 차이를 보였으며, 두 그룹 모두 빈도 및 조합확률이 모두 낮은 조건에서 그렇지 않은 조건에 비해 유의하게 부족한 수행을 보였다. 단순언어장애 아동의 문법 성 판단 수행은 빈도 및 조합확률이 모두 낮은 조건과 유의한 상관이 있었으며, 단순언어장애 유무를 가장 잘 판별해주는 조건은 LH (low probability/high frequency)로 나타났다. 논의 및 결론: 단순언어장애 아동이 또래 일반 아동 집단 아동에 비해 특정 규칙이 적용 될 때 빈도와 조합확률 모두 낮을 경우 규칙에 대한 민감도는 더욱 저하되며, 이러한 어려움이 이들의 문법성 판단 수행과도 밀접한 연 관성을 나타낸 것으로 분석된다.

핵심어: 암묵적 학습, 단순언어장애 아동, 문법성 판단, 조합확률, 인지적 유연성

본 연구는 이화여자대학교 교내연구비 지원에 의한 연구임.

\section{참고문헌}

김영태, 홍경훈, 김경희, 장혜성, 이주연(2009). 수용·표현어휘력검사(REVT). 서울: 서울장애인종합복지관.

문수백, 변창진(2003). K-ABC 교육·심리측정도구(Korean-Kaufman assessment battery for children). 서울: 학지사.

박예지, 김영태(2015). 인공 문법 학습 (AGL) 과제를 통한 읽기장애 아동의 명시적 학습능력과 암묵적 학습능력. 언어청각장애연구, 20, 518-535.

임동선, 양윤희, 조연주, 이지연, 성지민(2015). 학령전기 단순언어장애 및 일반아동의 문법성 메타언어인식과 집행기능 수행능력 비교분석. 언어치료

연구, 24, 345-359.

정필연, 임동선(2016). 조음음운장애아동의 음운인식능력과 암묵적 학습능력 간의 관계. 언어청각장애연구, 21, 37-46. 